\title{
E-Learning Platforms as Leverage for Education for Sustainable Development
}

\author{
By Liliana Donath ${ }^{1}$, Gabriela Mircea ${ }^{2}$, Tomislav Rozman ${ }^{3}$
}

\begin{abstract}
The paper is a conceptual approach to education for sustainable development using an e-learning platform. It starts from the observed reality that all education stakeholders need a learning environment where they can have access to knowledge, collaborate and share their experience, as a survey conducted among students and companies in Timisoara, Romania, region shows. The proposed multi-stakeholder environment accommodates two sections: the learning environment mostly dedicated to students, trainees, tutors and mentors and the virtual sustainability centre that is dedicated to on-line meetings, workshops, counselling, etc. Durable learning is supported by a range of written digital and multimedia resources, including pre-recorded on-line tutoring, videos and games. To engage online learners, various gamification techniques were used in the course design phase, such as recording and presenting the learner's progress, role-playing and similar. The article presents a conceptual design of the learner's journey and a mapping from gamification concepts to Moodle LMS elements.
\end{abstract}

Keywords: E-learning, education, sustainable development, gamification, LMS

\section{Introduction}

Education is going through major transformations induced by students' expectations, the dynamic of communication tools and of the labour market, the shift towards unprecedented skills and competencies that are needed to accommodate the requirements of sustainable businesses, i.e. enhanced risk-return-performance, long term strategy and endurance, increased reputation. Moreover, regulatory developments, a wide range of screening and benchmarking are also supported by this educational approach.

The exigency to address urgent sustainability issues has placed universities and, mainly, business schools at the heart of the changing paradigms in the economy and society that are interwoven with the dynamics of the environment. In this context, business schools are challenged to prepare graduates able to act sustainably to prevent future economic, financial and social crises. The responsibility comes from their specific position in society and the complex nature of the curricula that covers economic, financial, managerial, information systems topics. Furthermore, their connection with businesses, institutions and the civil society is the foundation of knowledge transfer to all levels of societal structures and policymakers as well.

Nevertheless, embedding Education for Sustainable Development (ESD) in the curricula is not an easy task, because, often, it is not straightforward how ESD fits the internal

${ }^{1} \mathrm{PhD}$, Professor, Department of Finance, Faculty of Economics and Business Administration, West University of Timisoara, Romania

${ }^{2} \mathrm{PhD}$, Professor, Department of Business Information Systems, Faculty of Economics and Business Administration, West University of Timisoara, Romania

${ }^{3} \mathrm{PhD}$, BICERO Ltd., Maribor, Slovenia 
organisation, strategies and mainstream approach of a business. But, from a different perspective, when there is a consensus between the internal environment and the ESD requirements the entire process is successful. The manner universities choose to include ESD varies. It is either an academic endeavour, elements of ESD being adapted and inserted in each syllabus or, in a more comprehensive manner, within Sustainability centres. Business Schools that are leaders in ESD have concentrated on developing Sustainability centres based on three tiers: technical, cultural and political (Slager et al., 2018).

The article is founded on a survey conducted at major Universities located in Timisoara campus, Romania, to identify the perception of students and stakeholders concerning the skills that are acquired in the field of sustainable development. Based on the results of the survey, it was concluded that the best way to approach ESD is within a multistakeholder digital learning environment (that includes a virtual Sustainability centre). Hence, this article presents the authors' view on how an e-learning platform (developed for the use of various education stakeholders) can enhance ESD in tertiary education thus improving the students' skills in this field.

The paper has a twofold aim, i.e. educating for sustainable development and providing a tool for sustained and durable learning. Starting from the available literature, the paper presents the manner ESD can be approached in a holistic, dynamic and multilevel manner and e-learning is promoted as a suitable tool for ESD among those available to higher education institutions. Hence, the paper contributes to the literature by going beyond the technical aspects of such platforms, rather emphasizing the nature of ESD learning and its outcomes. Though e-learning platforms have been in use for some time, additional debate is needed concerning the adaptability of the content to various learning topics, therefore the paper is intended to contribute to this debate.

Focusing on the student-centred learning approach, the content of the e-learning platform serves as leverage not only for ESD but also for durable long-standing learning. It raises awareness about sustainability and provides incentives (nudges) for further studies according to the interest of the beneficiary rather than providing the typical frame to study sustainability topics. It also allows for flexibility, the user being able to choose the level of knowledge to be acquired. On the other side, the teacher becomes a tutor, mentoring and guiding the learner on its path to understand and apply and act sustainably.

The paper is structured as follows: Literature review; The need for a multi-stakeholder learning space; A multilevel ESD learning using e-learning platform; Sustainability centre as a multi-stakeholder collaborative environment. The remainder of the paper is dedicated to Conclusions, Limitations and Further research.

\section{Literature Review}

Sustainability, sustainable development, acting in a sustained manner are concepts largely used to describe situations or actions that must be durable, with different connotations (Smith et al., 2013). Numerous articles, books, debates emphasize its meaning when relating the nexus between economy, society and environment. But, ESD seems to be more daunting, since the potential methods are not holistic enough to 
incorporate all aspects of sustainability. The complexity of the transitioning process from the traditional, mainstream education and training approach towards the new paradigm makes literature on this topic rather scarce or dissipated. Maybe the best way to address it is Socrates's way: "I cannot teach anybody anything. I can only make them think." In the present circumstances, universities, as knowledgeable leaders in the community, can play a major part in promoting education for sustainability having a broad responsibility in completing the Sustainability Development Goals (SDG) and, as literature argues, ITC can play a crucial role in implementing these goals (Wakunuma \& Jiya, 2019).

Since the concept of sustainability embeds numerous aspects that can be traced and dealt with systematically, ESD, per se, is a complex issue being subject to the unknown and unpredictability. Therefore, it requires a high level of communication, interaction and expertise accompanied by patience to depict new behavioural patterns. In this context, universities play the role of innovators by using their research culture, education infrastructure and wide networks. They can offer in-depth knowledge through their curricula and operational area (Howarth et al., 2019) or informal and lifelong learning education as inclusive players in promoting sustainability.

Researches (Laurie et al., 2016) confirm that when the curriculum includes sustainability topics, teaching and learning are transformed at all levels of education also transferring knowledge in the society to understand the practical meaning of sustainability.

Authors (Rozman \& Rozman, 2020) investigated a similar topic and found out that sustainability-related issues are being integrated to some extent within educational system (kindergarten, primary, secondary, tertiary and lifelong learning) in Slovenia, EU. Nevertheless, their research among adult professionals shows that their recall of sustainability-related topics from their education path is not very positive. Almost all professionals missed the aforementioned topics and now they are trying to gain sustainability-related competences as adults in various training. The research also showed which learning techniques are currently used by the sustainability training centres on the market. Most of them provide traditional live training and handbooks, which confirms the need for on-line training with modern e-learning approaches.

The fundamental philosophy of ESD regards sustainable economic growth, diversity and equal chances, energy, climate change, biodiversity, energy, cultural heritage, etc. But, though often mentioned in literature, policies or everyday situations, ESD is still addressed cautiously, not being fully embraced by all educational stakeholders (Exter et al., 2013). This attitude is understandable to a certain extent given that the concept of sustainability is often regarded as too abstract, too theoretical or too blurry but, eventually, these misconceptions are related to one's feelings towards sustainability (Filho, 2011). Ultimately, from a practical perspective, ESD relates to three stages that should be covered for a successful implementation: the context of learning, the content of learning and the process of learning (UNESCO, 2018).

The present paper reiterates the need for active learning, involving interactive methods, detailed in the literature (Kostyuchenko \& Smolennikov, 2016), that meet the requirements of sustainability-related knowledge. Among these, debates, role-playing, gamification, case studies and simulation contribute to durable learning. But, such an approach needs a specific multi-stakeholder environment, that reunites all collaborators that support the learning process and that constitutes the main contribution of the 
present paper.

By using e-learning platforms, students enter a friendly environment which they may create themselves under the guidance of a tutor. Such collaborative platforms reunite a wide range of working teams (trainers and trainees), the information being widespread to the outer circles of the university.

E-learning platforms, per se, meet the demand for sustainability tools in education, providing numerous advantages and opening the gates to new opportunities in learning. Learning oriented education has a better choice in using e-learning platform, students being able to build their environment through networking and connecting. They are also inclusive, allowing students from rural and/or remote areas to be part of the learning community. Nonetheless, like other types of platforms, e-learning may be vulnerable and volatile in a competitive market and counterfeits are difficult to control (Zarra, 2019). Most often, though, ESD platforms deal with environmental issues, rather than a holistic approach including economic and social issues, even though, when asked, people tend to add weight the latter (Kopnina \& Meijers, 2012).

Arguably, the e-learning platforms address different age groups who have different levels of knowledge in using digital means but want to access knowledge. Therefore, they must be designed flexible, adaptable and easy to use and answer all requirements. They should be considered means that raise competences, develop communication skills, encourage tolerance, promote inclusion, etc. Therefore, stimulating collaborative learning as studied by Hsiao et al. (2014) is important within a multi-stakeholder digital environment such as Sustainability centres. But, as learning stimuli, nudges work best, since they allow students to opt-in or out the learning environment, can choose their learning path under the guidance of a tutor, can manage their own time allocated for learning. Moreover, nudges can raise students' interest and individual motivation.

Compared to other publications, the present paper does not focus on technical issues that are well documented in the literature but rather looks at the manner e-learning platforms can be designed as learning centres (Donath, 2017). It also supports blended learning (Crawford \& Jenkins, 2017), allowing progressive team teaching and encourages the complementarities of various learning methods, i.e. visualization using video, games, problem-based learning (PBL), pre-recorded online discussions and face to face meetings.

Because self-assessment is encouraged (Charteris et. al, 2016), using the appropriate tools that project a critical view of one's learning progress becomes crucial. It is also safe to say that the paper complements the idea stated in the literature that students need an educational context that provides the necessary skills to act as ESD citizens and agents of change (Garrecht, et al, 2018).

\section{The Need for a Multi-Stakeholder Learning Space}

Sustainability oriented generation $\mathrm{Y}$ acknowledges the importance cross-sector issues including the environment, ethics, social equity, economics, politics, etc. seeking to contribute by acquiring new expertise in line with the changing labour market requirements. Given the complexity of sustainable development, the involvement of all stakeholders is needed to define the required expertise: students, academics, businesses, 
the community, information for policymakers, etc.

In the paper, the need for a multi-stakeholder learning space has been identified starting, firstly, from the evolution of selected sustainability indicators in Hungary, Romania and Slovenia in recent years, shown in the Figures below.

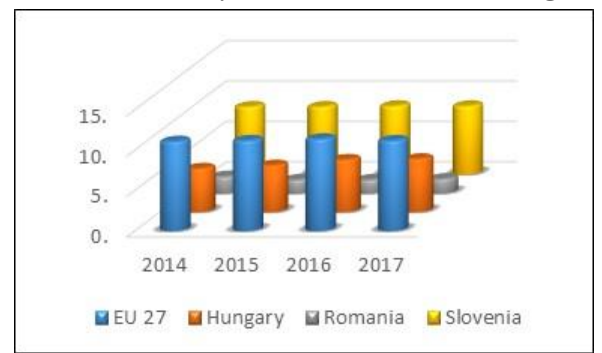

Figure 1 Circular material use (\%)

Source: Eurostat

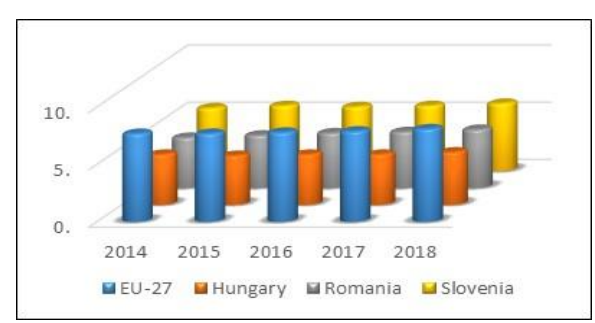

Figure 3 Energy productivity

Source: Eurostat

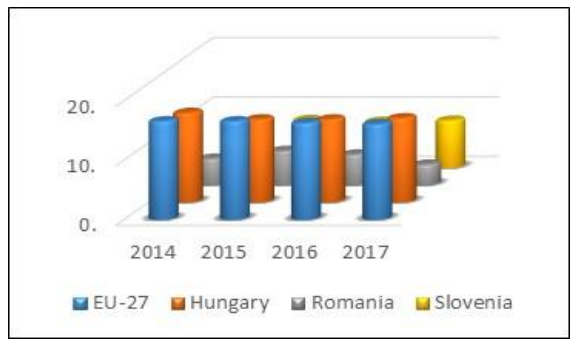

Figure 5 Gender pay gap

Source: Eurostat

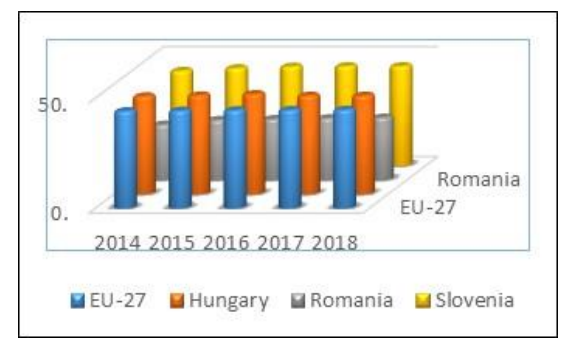

Figure 7 High tech employment

Source: Eurostat

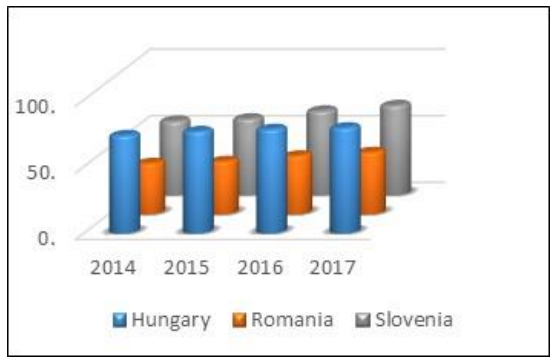

Figure 2 Access to water waste treatment (\%) Source: Eurostat

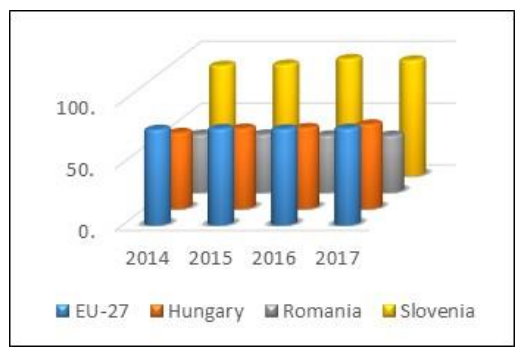

Figure 4 Greenhouse emissions $(1990=100)$ Source: Eurostat

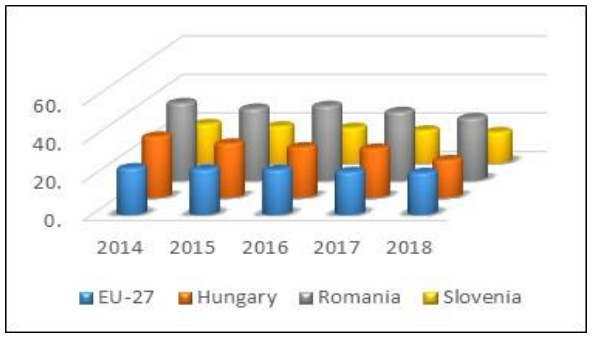

Figure 6 Risk et poverty

Source: Eurostat

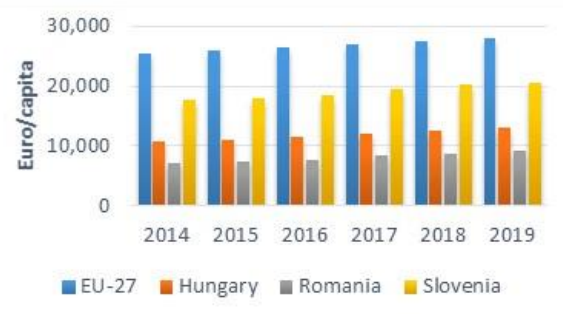

Figure $8 \mathrm{GDP} /$ capita

Source: Eurostat 
Secondly, a survey was conducted among students from technical, medical and The West University Timisoara (313 valid responses were received), to identify the sustainability skill gaps to meet the needs of future professions (Donath et al., 2020). The percentage of respondent students/university by number and gender is given in Figure 9:

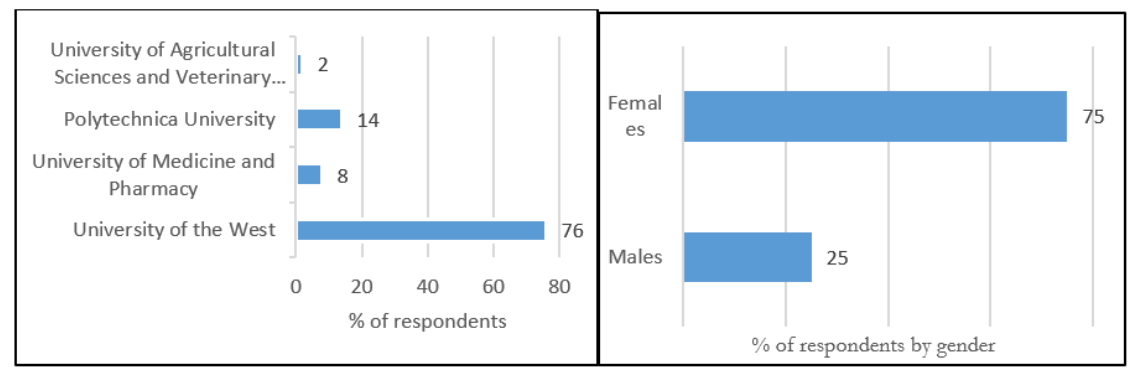

Figure 9 Percentage of respondents by number and gender

The questions mainly targeted the quality of academic information and the acquired skills during their studies are given in [Figure 10]:

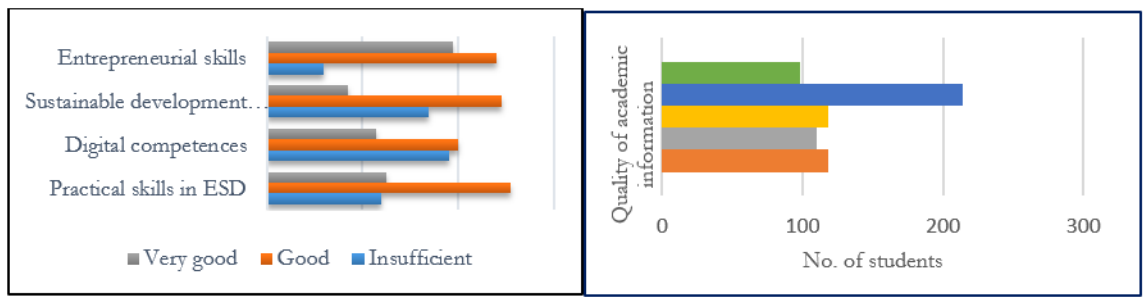

Figure 10 The perception of students regarding the acquired skills and the quality of academic information

The most preoccupying issues for students from a sustainability perspective were [Figure 11].

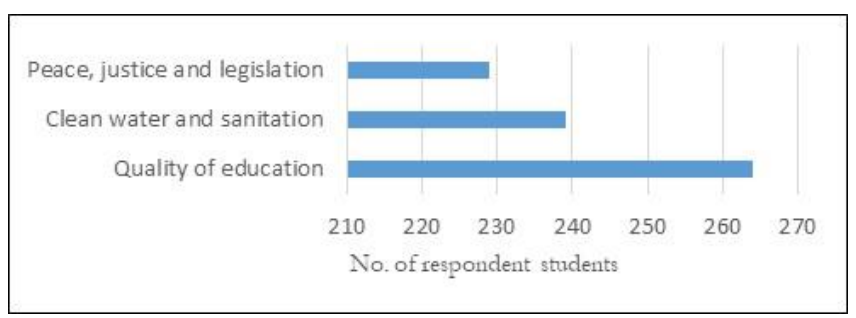

Figure 11 The most preoccupying issues for the students'perspective

Additionally, an interview was addressed to the most influential companies located in the Western part of Romania that employ most of the students. The interviews addressed to companies targeted their involvement in academic-related activities, the importance of ESG CSR in company policies, the level of students' knowledge in these areas, the manner companies address lifelong learning is addressed. The summary of answers is given in Table 1. 
Table no1. Summary of company interviews

\begin{tabular}{|c|c|c|c|c|c|c|}
\hline \multicolumn{5}{|c|}{ Academic investments } & \multirow{2}{*}{$\begin{array}{c}\text { ESG and CSR } \\
10 \% \\
\end{array}$} & \multirow{2}{*}{$\begin{array}{c}\text { Lifelong } \\
\text { learning }\end{array}$} \\
\hline $93 \%$ & $33 \%$ & $100 \%$ & $60 \%$ & $20 \%$ & & \\
\hline Soft skills & Hardware & $\begin{array}{l}\text { Education } \\
\text { scholarship }\end{array}$ & $\begin{array}{c}\text { Students } \\
\text { Academic } \\
\text { competitions }\end{array}$ & $\begin{array}{c}\text { Targeted } \\
\text { scholarships } \\
\text { for selected } \\
\text { students }\end{array}$ & $\begin{array}{l}\text { Workshops: } \\
\text { environmental } \\
\text { and social } \\
\text { issues }\end{array}$ & $\begin{array}{l}\text { Professional } \\
\text { training }\end{array}$ \\
\hline $\begin{array}{l}\text { Sustainable } \\
\text { investment } \\
\text { workshop }\end{array}$ & Software & $\begin{array}{c}\text { Young } \\
\text { researchers' } \\
\text { and } \\
\text { entrepreneurs } \\
\text { scholarships }\end{array}$ & $\begin{array}{l}\text { Talent } \\
\text { hunting }\end{array}$ & \begin{tabular}{|c|} 
Supporting \\
tuition \\
fees for top \\
students and \\
PhD students
\end{tabular} & $\begin{array}{l}\text { Case studies } \\
\text { in } \\
\text { sustainable } \\
\text { auditing } \\
\text { reports }\end{array}$ & $\begin{array}{l}\text { Professional } \\
\text { certification }\end{array}$ \\
\hline $\begin{array}{l}\text { Training and } \\
\text { case studies }\end{array}$ & $\begin{array}{c}\text { Learning } \\
\text { Infrastructure }\end{array}$ & $\begin{array}{l}\text { Joint research } \\
\text { academics- } \\
\text { students- } \\
\text { companies }\end{array}$ & Internship & $\begin{array}{c}\text { Brand } \\
\text { awareness }\end{array}$ & $\begin{array}{l}\text { Voluntary } \\
\text { activities }\end{array}$ & $\begin{array}{c}\text { MBA } \\
\text { certification }\end{array}$ \\
\hline $\begin{array}{c}\text { Career } \\
\text { orientation }\end{array}$ & & $\begin{array}{c}\text { Conference and } \\
\text { seminar } \\
\text { sponsorship }\end{array}$ & Gamification & $\begin{array}{c}\text { Business } \\
\text { angels for new } \\
\text { business } \\
\text { initiatives }\end{array}$ & Green motion & $\begin{array}{l}\text { Online } \\
\text { libraries }\end{array}$ \\
\hline $\begin{array}{l}\text { Curricula } \\
\text { input }\end{array}$ & $\begin{array}{l}\text { Co-working } \\
\text { spaces }\end{array}$ & $\begin{array}{c}\text { Internship and } \\
\text { students. } \\
\text { NGOs } \\
\text { sponsorship }\end{array}$ & & & & $\begin{array}{c}\text { Postgraduate } \\
\text { studies }\end{array}$ \\
\hline $\begin{array}{l}\text { Alternative } \\
\text { education } \\
\text { initiative }\end{array}$ & $\begin{array}{l}\text { Supporting } \\
\text { educational } \\
\text { hubs }\end{array}$ & $\begin{array}{c}\text { Best students' } \\
\text { award }\end{array}$ & & & & \\
\hline
\end{tabular}

Given the above evidence, it was concluded that the best manner both students' and companies' expectations can be met is by designing a dedicated e-learning platform that serves as a learning environment as a well as a multi-stakeholder collaborative environment.

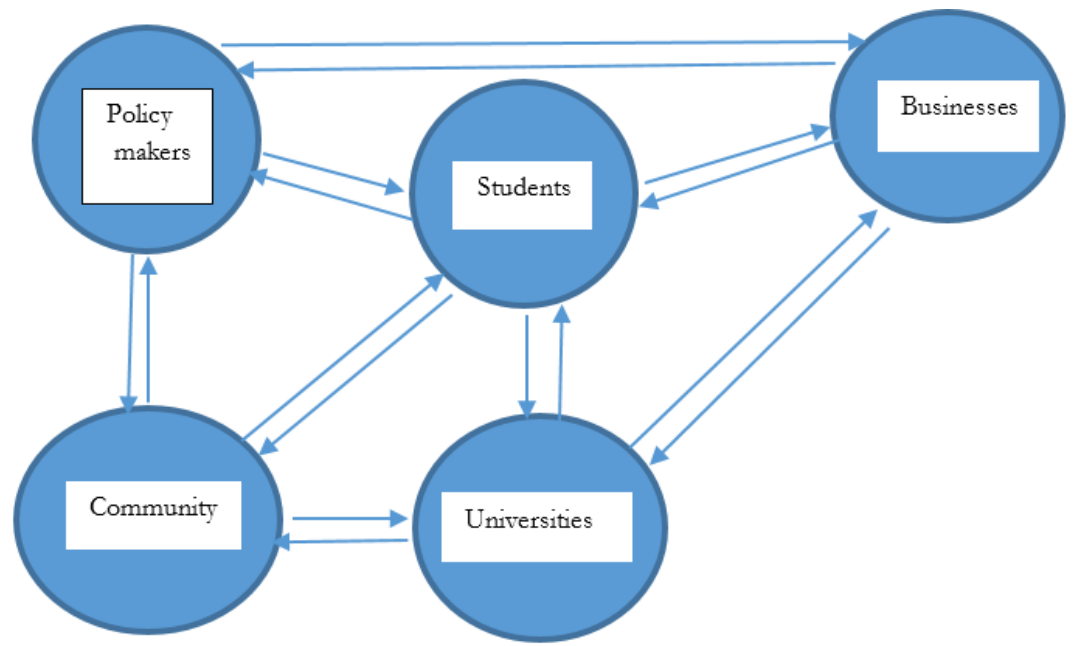

Figure 12 The circular informational flow among education stakeholders 
The survey emphasises the strong connection among various education stakeholders [Figure12] and serves as a prerequisite for the necessity of a multilevel e-learning platform blueprint. It supports the endeavour to create sustainable learning, a collaborative environment in order to: enhance the general learning process and particularly lifelong learning, well-prepared students adapted to the new labour market requirements, education cost-effectiveness, cooperation and mutual respect among stakeholders. As the survey shows, there is an urgent need for concrete learning tools to fill the gap in sustainability-related issues.

\section{A Multilevel ESD Learning Using an e-Learning Platform}

The e-learning platform, developed by TeachSuS project consortium, is based on the choice architecture (Thaler, 2009) principles to support the transfer and integration of sustainability-related knowledge to higher education institutions, to ensure students' skills to address sustainability-related issues. In this respect, authors investigate education management to implement ESD (Suriyankietkaew \& Hallinger, 2018) The choice architecture approach is relevant in this case because it allows students and other stakeholders to opt for the most suitable learning/training alternative among those put forward. It also considers the benefits of e-learning as discussed by Stoeva (2018).

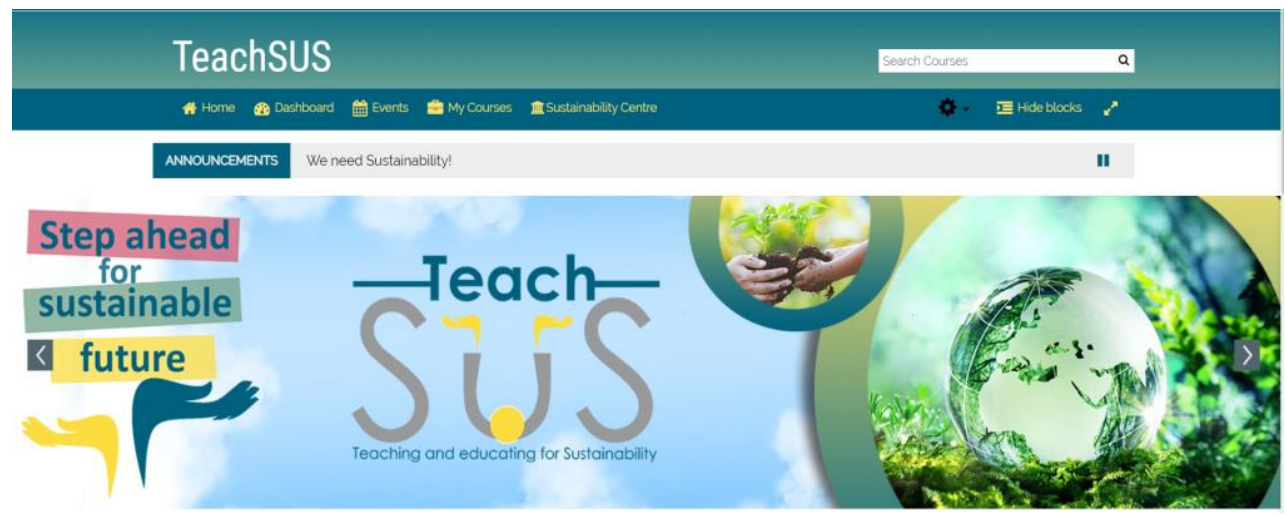

Figure 13 TeachSuS ITEC platform interface http:/ teachsus.projects.uvt.ro/

It is implemented using Moodle LMS with additional gamification plugins and is designed as an online learning environment and includes two main sections:

The learning environment: mainly dedicated to students and tutors/mentors and consists of:

- The training set: the training portfolio is structured to accommodate the main modules and learning elements that students opt either to attend online courses and solve case studies or meet tutors online for consultation and advice;

- Evidence collection: the system includes portfolio management and skill assessment features; students can upload the completed tasks and an assessor can evaluate the acquired skills. 


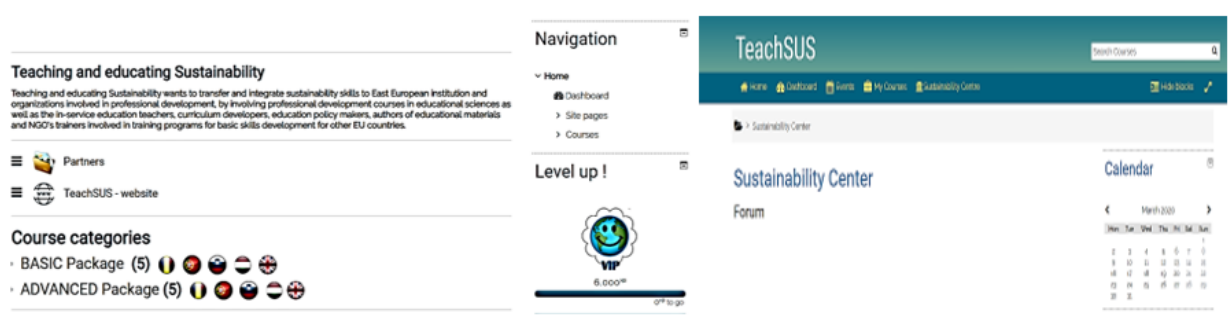

Figure 14 TeachSuS IT \& C platform. The learning environment and The Sustainability centre

The multi-stakeholder collaborative environment (i.e. The sustainability centre) is designed to act as a knowledge-sharing point for an active member, giving them the possibility to collaborate, to work together and share their experience in sustainability.

\subsection{The learning environment}

\subsubsection{Conceptual design of the learner's journey and gamification}

The trend of gamification mechanism usage in various contexts (sales, marketing, learning, human resource management) is increasing (Rozman \& Donath, 2019). Gamification mechanisms and game elements are used in course design to build learner resilience and motivation. It starts by profiling players, designing learner's journey and creating an achievement system with one goal in mind: to meet learning outcomes. The learning courses can be gamified by 1. gamifying the learner's journey and the interaction with the LMS and/or 2. Gamifying the content of the course. This paragraph focuses on the first approach. (Deterding et. al., 2011) distinguish game design elements based on the level of the abstraction, from concrete (level 1) to abstract (level 5) [Figure 15].

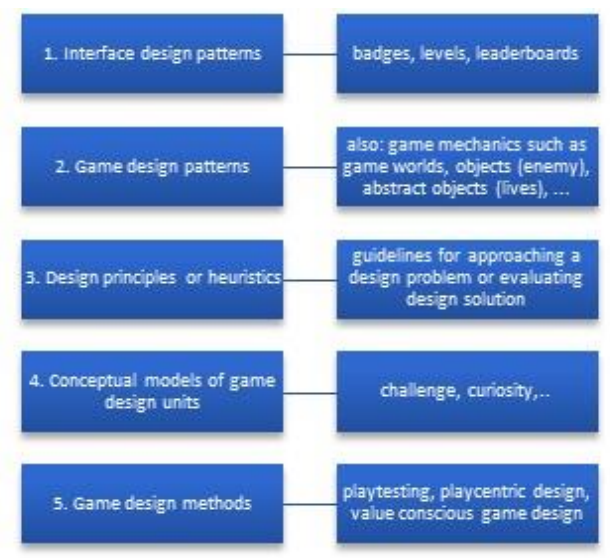

Figure 15 Gamification levels of abstraction

Onwards, when designing an online course, the starting point was the $4^{\text {th }}$ level [Figure 6]. The design of our course started with the learner journey design. For that purpose, BPMN2.0 process modelling technique was used to sketch the learner's interaction with the LMS. 
The gamified e-learning process was modelled using 2 conceptual levels. The first conceptual level was divided into three main phases: P01 Initiation of learner's journey, P02 Core of the learner's journey and P03: Post journey phase and assessment. The process shows the conceptual design - an example of how to implement gamification concepts into e-learning. The first conceptual level shows only the main phases and inputs/outputs of the e-learning process (blue information objects).

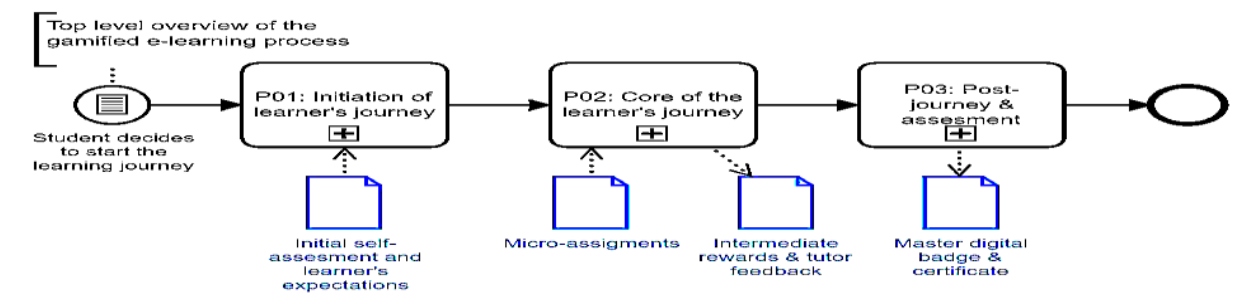

Figure 16 Top-level e-learning process

Each of the main sub-processes/phases was further derived to show details of each phase. Green/shaded activities include gamification concepts, which are further explained with comments below the activities. The next 3 detailed sub-processes show the activities of the following roles: learner, tutor, LMS (learning management system), BadgR (digital badge issuing and backpack platform), FB group.

The initial phase starts when the learner decides to take an online course. After the registration, the tutor activates the course and greets the learner. LMS introduces the learning buddy (virtual character) to a learner and the mission introduction, where storytelling is used to engage the learner. The learner is introduced to his/ her role (e. g. sustainability manager).

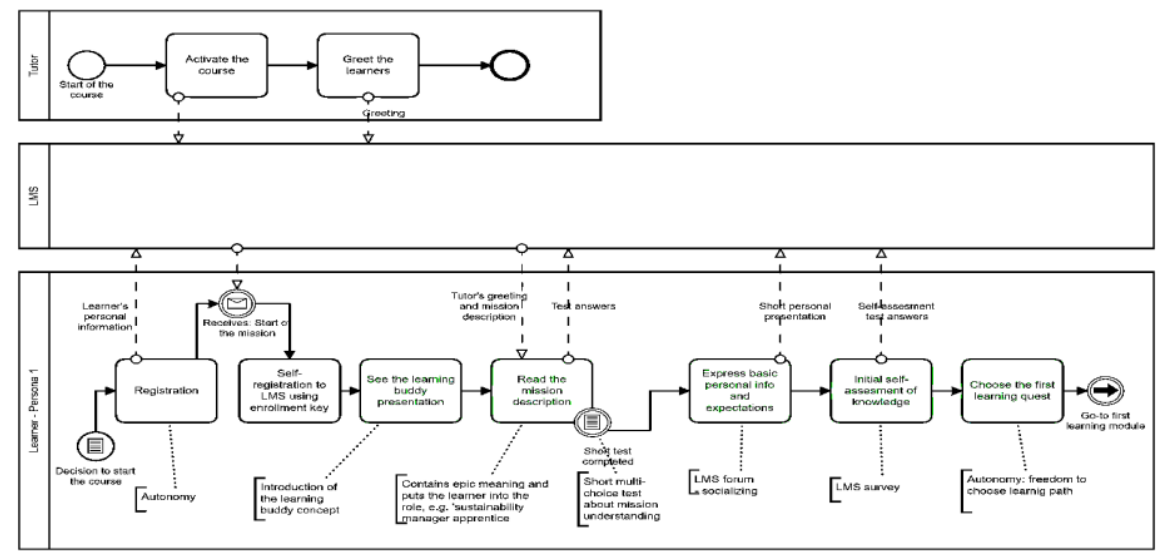

Figure 17 P01: Initiation of learner's journey

Further on, the learning buddy challenges the learner's role with various tasks. Each learner activity contributes to experience points. Each lesson ends with a multiple-choice question, to prevent jumping to the next lesson. The course is structured in several quests which end with a short practical written assignment. For example, the learning 
buddy introduces a challenge to a learner: "You are a sustainability manager in a company. The last month's utility bill, especially water consumption is way too high. The company manager wants to lower consumption. Can you prepare a short plan of action to reduce water consumption in your company?"

When the learner submits the assignment to the LMS, the tutor reviews it and provides feedback. When all assignments are completed, the learner should complete the final assignment ("the big boss battle"). After completing it, the process continues to the post-training phase.

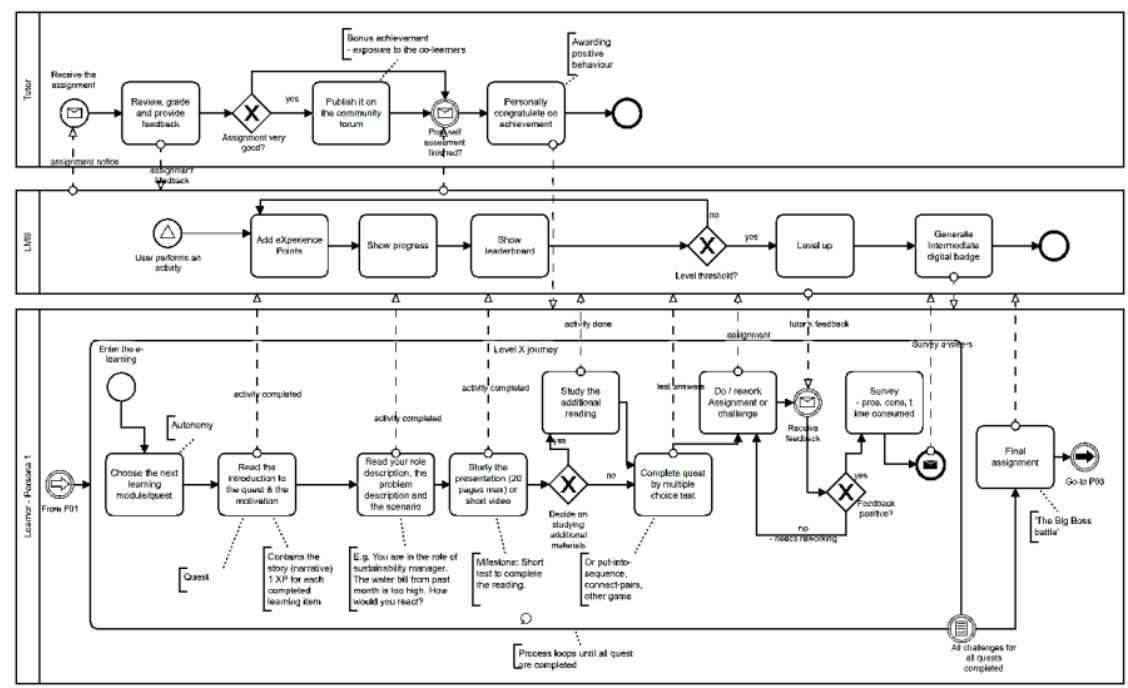

Figure 18 P02: Core learner's journey

Post-journey phase includes final self-assessment and comparison with initial assessment results. The LMS informs the tutor the learner completed the course. Then the tutor issues the master badge using BadgR.io system and generates a certificate. Lastly, the learner fills-in the satisfaction survey and the tutor publishes his achievement in the social media group of the course.

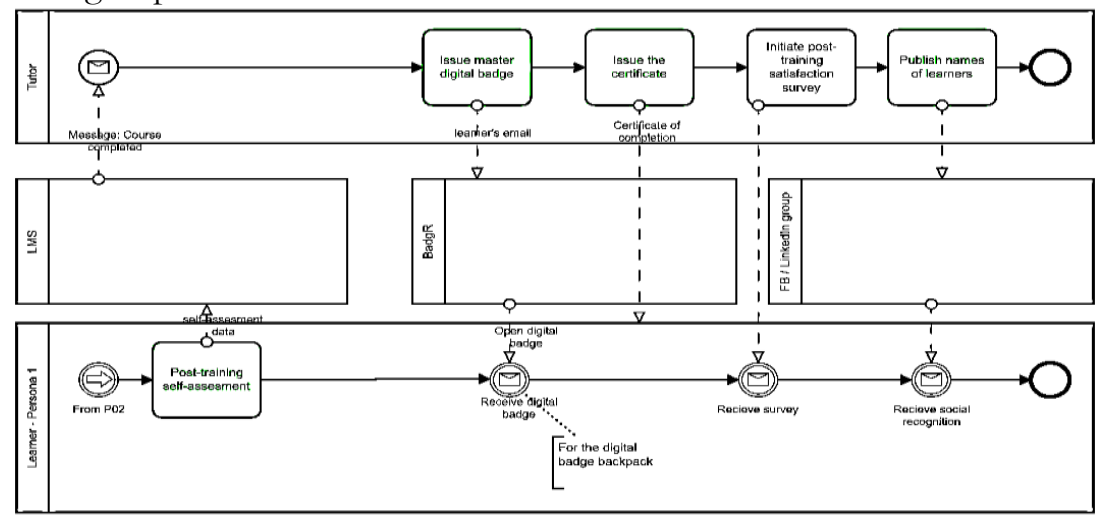

Figure 19 P03: Post-journey \& assessment 
The process models in this chapter show the AS-IS state of the learner's journey, events, touchpoints with the LMS system and the tutor. Comments show which gamification mechanisms are used at different phases of the process. The process model represents the base point for the learner's journey improvement. When the learner journey is represented with the process model, it is easier to discuss possible improvement points with course designers a, content creators and gamification experts.

Onwards, levels 3-1 of the course design are presented.

\subsubsection{LMS setup, course categories, folder organization}

The suggested learning patterns are simple to be sufficiently transparent and/or are accompanied by visualisation that developmental images. Thus, according to the context, either default learning (in unfamiliar circumstances when a degree of standardisation is useful), active choosing (opted for in familiar circumstances when individual learning is perceived as beneficial) or personalised defaults are applicable (addressed to well-informed agents that act in a heterogeneous context).

The learning environment encourages progressive learning required by the present learning complex systems by:

- adopting the test-learn-adapt sequence and stimulating the skill to respond- reflectrethink- recalibrate an assignment

- choosing between: discovery learning, collaborative learning, interdisciplinary learning, critical thinking learning, social learning etc. according to each one' motivation.

- it relies on bite-size information to accommodate students' learning profiles.

The e-learning platform is independent and centrally managed by the TeachSuS consortium partners. However, the learning modules can be transferred into the partners' e-learning environments (Moodle export packages or SCORM modules). The e-learning courses contain several micro-learning modules, self-assessments, quizzes, tests, assignments and similar learner's activities. E-learning gamification principles are used, which will be described below.

The Learning environment includes two levels: the BASIC Package and the ADVANCED Package. In both packages, the learning modules cover Technical and Soft skills topics, both available in English and native languages of users. In line with the choice architecture method recommendations, all courses provide alternative learning possibilities, e.g. PowerPoint presentations, self-study materials, video resources (and other digital resources, games, pre-recorded tutoring, links to additional learning sources; e-library/case studies, short test/quiz; assignment, discussion forums, chat, choice, database, feedback, forum, glossary, lesson, external tool, SCORM, survey, wiki, and workshop. The courses cover several selected sustainability-related issues, with the possibility to extend the range of topics according to needs: 'Sustainability dimensions', 'Health \& Wellbeing', 'Diversity and equals chances', 'Climate change mitigation and adaption' enriched with 'Communication' and 'Information transfer' methods and techniques are introduced in the BASIC Package folder. Advanced approaches cover 'Economic growth', 'Waste management', 'Water management', 'Energy management' theoretical aspects and representative study cases. Additionally, the enrolled learners can access learning resources on 'Public speaking', 'Engagement and motivation' and 'Train 
the 'Trainer' [Figure 20].
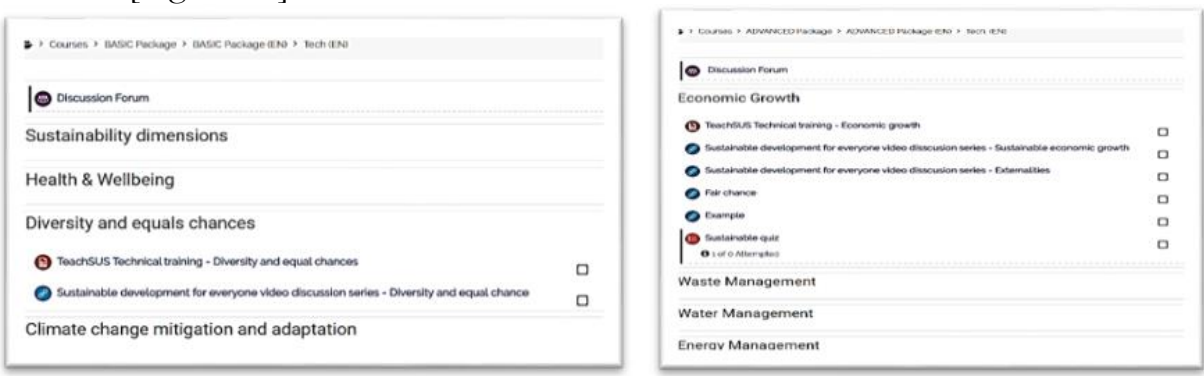

Figure 20 Course categories. Folder organization

Digital resources are organised on micro-modules because of the short attention span of today's learners. After solving the quizzes and assignments the learners can self-assess the level of acquired knowledge, their progress being awarded accumulated points and badges. Either in a weekly format or a topics format, courses are divided into micromodules or sections. Each micro-module/section contains one or more activities (Assignment, Chat, Choice, Database, External tool, Feedback, Forum, Glossary, Lesson, Quiz, Registration date, SORM Cloud Course, SCORM package, Survey, Wiki, Workshop).

The courses are grouped into two categories to provide technical skills and soft skills, and Learning is supported by PowerPoint presentations, pre-recorded videos and prerecorded discussion series to summarise the main ideas.

\subsubsection{Gamification of learning within the Moodle platform}

Various researchers such as (Petroulis, Tzelepi, \& Papanikolaou, 2019) have confirmed the effectiveness of implementing the rewarding mechanisms to the Moodle courses. Moodle LMS allows gamification of the on-line courses to some extent using separate plugins such as LevelUp!, Stash, Game, Quizventure and similar. These plugins allow the implementation of rewarding / PBL mechanisms (Points, Badges, Leaderboards) and simple games.

Based on the course structure previously defined, gamification activities are implemented by the following Moodle activities or functions [Table 2].

The course uses Level up! plugin, which provides gamification of learning with the following features:

- Automatically captures and attributes experience points to students' actions;

- Block that displays current level and progress towards the next level;

- Report for teachers to get an overview of their students' levels;

- Notifications to congratulate students as they level up;

- A leader board to display the rankings of the students;

- Ability to set the number of levels, the points they require;

- Images can be uploaded to customize the appearance of the levels. 
Table 2. Moodle activities

\begin{tabular}{|l|l|}
\hline GAME ACTIVITY & MOODLE ACTIVITY \\
\hline $\begin{array}{l}\text { Accomplishment of personal } \\
\text { adventure }\end{array}$ & $\begin{array}{l}\text { Studying learning resources. Accomplishment of personal } \\
\text { Assignment. Solving tests (quizzes) }\end{array}$ \\
\hline $\begin{array}{l}\text { Accomplishment of team } \\
\text { adventure }\end{array}$ & Accomplishment of group assignments \\
\hline Repetition of adventure & $\begin{array}{l}\text { Repetition of learning resource/activity(with permission for } \\
\text { repetition) in order to achieve better results (points) }\end{array}$ \\
\hline Passage of level & Passage to the next learning section when a given criteria is met \\
\hline Level repetition & $\begin{array}{l}\text { Repetition of learning resources/activities (with permission) in } \\
\text { order to achieve missed badges }\end{array}$ \\
\hline Obtaining of badge & $\begin{array}{l}\text { Obtaining of badges, certifying successfully completion of } \\
\text { learning activities and achieving some learning objectives }\end{array}$ \\
\hline Obtaining of reward & Obtaining access to additional optional learning material \\
\hline Obtaining of points & Obtaining points from assessed learning activities \\
\hline $\begin{array}{l}\text { Discover hidden treasures } \\
\text { Opening of hidden or grayed-out learning resources/activities } \\
\text { completed }\end{array}$ \\
\hline $\begin{array}{l}\text { Feedback when progression is } \\
\text { noticed }\end{array}$ & Obtaining of badge or points. Teacher feedback \\
\hline $\begin{array}{l}\text { Time restriction for } \\
\text { accomplishment of adventure }\end{array}$ & \begin{tabular}{l} 
Setting up a time restriction of a learning resource or activity \\
\hline Personal communication
\end{tabular} \\
\hline Common communication & Chat/forum/shared files with another student or teacher \\
\hline
\end{tabular}

As the name suggests, every time a student gains sufficient points to unlock the next set of activities, he/she goes one level 'up'.

Further, some considerations regarding the quiz activity. It is a main and powerful activity "that can meet many teaching needs, from simple, multiple-choice knowledge tests to complex, self-assessment tasks with detailed feedback". Quizzes can contain a large variety of question types: multiple-choice, true-false, short answer, drag and drop images and text, etc. Quizzes are used in section checks [Figure 21 a], test practice and data gathering. They may imply to watch a video, considering its benefits according to (Fyfield, et.al, 2019) or listen to an audio resource and then answer a question. The quiz attempt result report can be received in the form of a progress bar [Figure 23].

Activity completion is enabled by default for all type of Moodle activities, including quiz activities. Depending on the type of activity, there can be different completion requirements. For example, a Quiz might have the requirement to require grade while a Forum might have the requirement to require posts/discussions/replies. Activity completion let the learner see his/her progress through the Moodle course by using checkboxes at the side of the activity.

\section{Technical skills (EN ..}

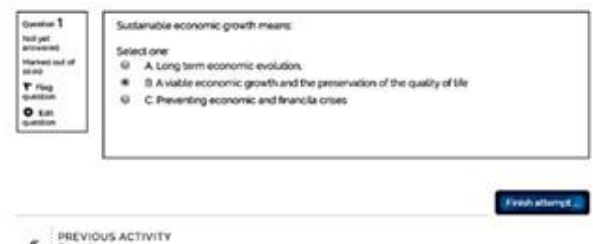

Figure 21 a Quiz example

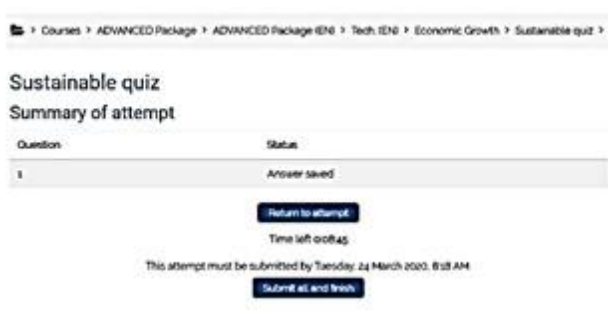

Figure 21 b Quiz attempt result 


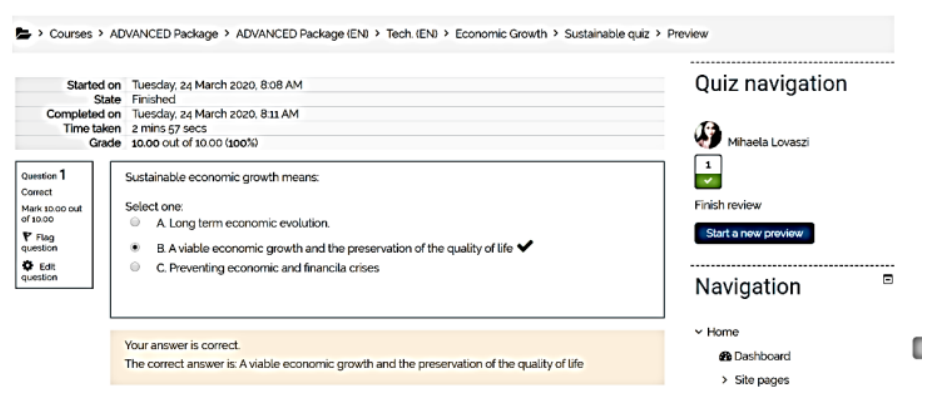

Figure 22 Answer validation

The Progress Bar is a time-management tool for students. It is colour coded and shows what has been completed/viewed and what has not been completed for each student. Students know the total points for the course, they know their cumulative total already graded (against the maximum available) and they know their current grade. Activities are graded by the teacher using a grading scale [Figure 24].

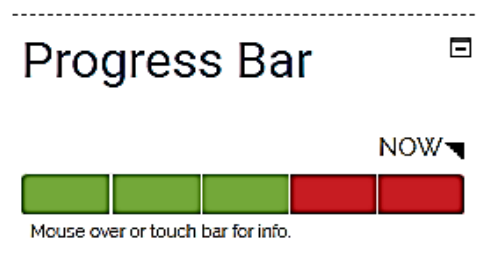

Overview of students

Figure 23 Gamification. Progress Bar

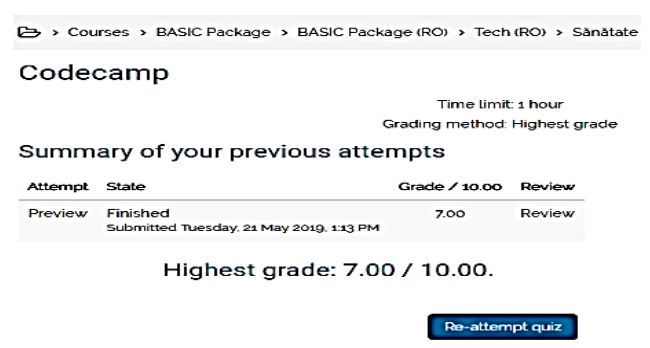

Figure 24 Display of results

Whenever a student makes a quiz, the obtained result versus the maximum grade is displayed [Figure 24]

\subsection{Sustainability centre as a multi-stakeholder collaborative environment}

The second part of the TeachSuS e-learning platform hosts The Sustainability centre. It is designed as a multi-stakeholder collaborative environment, that will act as a knowledge-sharing point for the active members of the multi-stakeholder collaborative environment.

The main aim of sustainability centres is to add value to formal education by covering issues that are not sufficiently elaborate. They may also act as link factors within regions that share common cultural values and can address sustainability issues within the local economic and social environment, or creating a local/regional knowledge base in which universities play the key role and provide guidance.

As global learning spaces, sustainability centres may be organised in various manners, from encouraging face-to-face communication to multi-sector platforms and networks, but promoting a partnership approach in its entirety. 


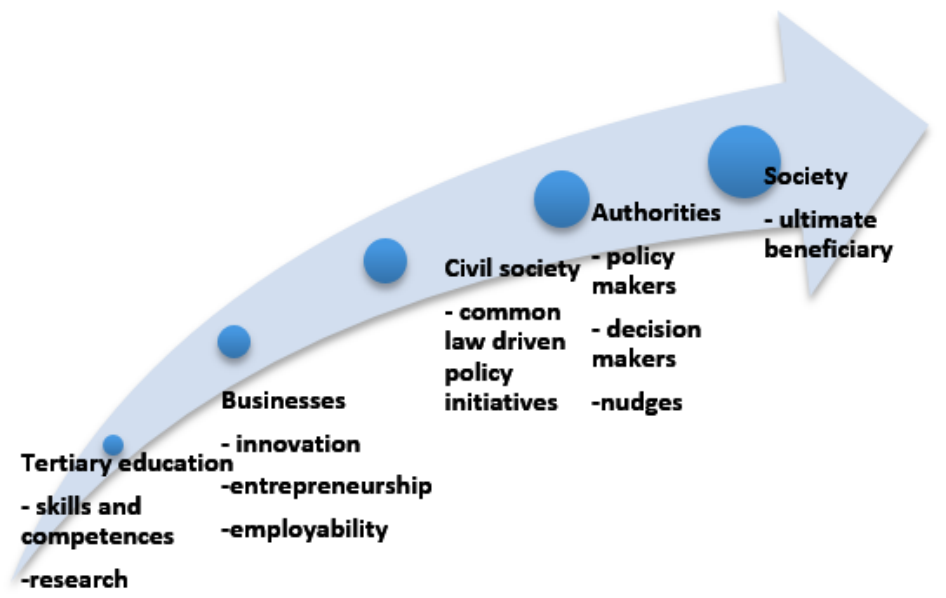

Figure 25 The transfer of skills acquired in tertiary education within the multi-stakeholder centre

The Sustainability Centre is based on the involvement and contribution of all stakeholders in the governance of knowledge, i.e. production, mediation and utilisation (De Burns et al., 2016). Thus, research-based knowledge is transferred from academia to businesses and society, the latter ones contributing to their practical expertise [Figure 25]. The knowledge complementarities are interwoven via e-learning platforms as hosts of various on-line debates, workshops, discussion forums, consultancy, etc. that broker realtime information and support regional and local development with minimal costs.

One can anticipate that the main role of the Sustainability centre is to foster innovation in all economic, social and environmental topics. Universities, as front runners in the community, can initiate mutual research projects with the business, the latter ones directly benefiting from the result; can fix the markets through behavioural insights. Moreover, the research outcome can attract entrepreneurs (start-ups), by diffusing the information that further develops applied research based on sustainable development principles. Ultimately, local communities can promote policies to enhance wellbeing.

The collaborative environment can also act as a nudge unit where multidisciplinary teams work on the diagnosis, analysis and behaviourally supported the design of policy interventions. Based on choice architecture, nudges allow for flexibility, libertarian-paternalistic incentives, avoid mandates and bans, promotes transparency and effectiveness (Thaler and Sunstein, 2009; Damgaard, 2019). It imposes low or no costs at all, due to default rules, simplification, use of social norms, transparency.

In this context of multi-stakeholder collaboration, it possible to identify the students' interests, motivation and behaviours, hence nudges (e.g. goal setting, responsibility in decision making, awards, etc.) for a durable education may be drawn up. Nevertheless, promoting sustainability-driven higher education, both in terms of economic development and learning systemically demands the involvement policymakers, who should support the followings: bridge the gap between education research - stakeholders - community, tutoring and mentoring, understanding the connection between theory and practice in the circular economy, through case studies, lifelong learning, creative thinking, a research-driven learning, teamwork, computer skills, 
soft skills, etc., foster entrepreneurial skills, sustainable business models, green procurements, applied research in sustainability, bridge the intergenerational gap, etc.), promote local culture and values and how they can be interconnected globally, investments in sustainable campuses that may trigger a change in students' behaviours that further on spillover in a beneficial manner on the community.

\section{Conclusions and Policy Lessons}

When applying ESD, universities are often challenged to implement the most effective tool that meets students' and companies' expectations, respectively. At this stage of research, the paper presents a conceptual contribution to the ESD emerging field, endeavouring to find the best methods of improving the ESD quality in universities in Romania. In this quest, based on the results of a survey conducted among students and companies located in the Western part of Romania, the conclusion that an e-learning platform was the most appropriate tool was reached. The content of the courses that are uploaded on the platform is intended to focus on the most preoccupying sustainability related topics for students and companies, thus all stakeholders can engage in solving these issues.

Considering the wide propensity towards digitalisation of the millennial generation and the following ones, as well as their preference to rather rely on default type presentations, problem-based learning and gamification, the paper promotes online learning, thus involving students and other stakeholders that are at distance and seeks to encourage collaboration and self-assessment. Since gamification is one of most agreed-upon learning method, the paper describes its implementation extensively, opting in or out of the game remaining at the core of the approach, given that, ultimately, personal motivation stands at the heart of durable education and the implementation of sustainable development desideratum.

The TeachSuS IT\&C platform is prepared to store all ongoing developed digital resources, to apply e-learning gamification principles, to support e-learning processes for a massive number of learners. The training set is structured into modules and learning elements. For each learning element slides, notes, video discussions will be available supporting the students in their attempt to solve exercises, study cases, and also meet tutors online to discuss the exercises. The system includes a portfolio management and skills assessment feature as well as a database of quizzes and tests for attendees. Students at the workplace can upload evidence of their skills and an assessor can evaluate the evidence. The design of the e-learning collaborative approach is based on the concept of choice architecture and is aimed at fostering students' performance, innovative behaviours, equity, autonomy in learning and consciously applying a sustainable way of living.

The envisaged impact of the integrative learning path is to nurture the students' capability to address the requirements of their fields of expertise and employability, understanding of nature through biodiversity and ecosystems, life support - resources and quality of the environment, community - cultures, but also connected issues like wealth, consumption, society institutions, social capital, regions, etc. Though e-learning platforms have been in use for some time, they are still a frontier field of study, mainly in 
their adaptability to various learning topics, level of study and complementarity to face to face courses. The paper is intended to be our modest contribution to this debate.

\section{Limitations and Further Research}

The paper presents a conceptual point of view on the manner education for sustainable development can be approached to improve students' competences in this emerging field. Since the suggested ESD learning method is at its early stages it must pass the test of time. Hence, it opens future research channels to identify the appropriate indicators to evaluate the impact of the approach and to empirically test its outcome.

\section{Acknowledgement}

The paper is based on research co-financed by the project "Teaching and Educating for Sustainability TeachSUS", Erasmus+ Programme Strategic Partnership, Project No: 2018-1-RO01-KA204-049253 (https://www.teachsus.eu/ ).

\section{References}

Charteris, J., Quinn, F., Parkes, M., Fletcher, P., \&Reyes, V. (2016). e-Assessment for learning and performativity in higher education: A case for existential learning. Australasian Journal of Educational Technology, 32(3), 112-122. https://doi.org// 10.14742/ajet.2595

Crawford, R., \& Jenkins, L. (2017). Blended learning and team teaching: Adapting pedagogy in response to the changing digital tertiary environment. Australasian Journal of Educational Technology, 33(2), 53-72. https://doi.org//10.14742/ajet.2924.

Damgaard, M.T., \& Nielsen, H., S. (2018). Nudging in education. Economics of Education Review, 64, 313-342. https://doi.org//10.1016/j.econedurev.2018.03.008.

De Burns, T, Köster, F., \&Fuster, M. (2016). Educational Research and Innovation Education Governance in Action Lessons from case studies. OECD Publishing Paris. https://doi.org// 10.1787/9789264262829-en.

Deterding, S., Khaled, R., Nacke, L., \&Dixon, D. (2011). Gamification: toward a definition. In CHI Gamification Workshop Proceedings, Vancowver, BC, Canada, Chi, 12-15. https://doi.org// 978-1-45030268-5/11/0.

Donath, L. (2017). A sustainability approach of higher education, Central European Higher Education Cooperation. In CEHEC Conference Proceedings. Corvinus University of Budapest, Center for International Higher Education Studies and Central European University. Retrieved from: http://unipub.lib.uni-corvinus.hu/3682/1/2nd_CEHEC Proceedings 2016 04.pdf.

Donath, L., Boldea, M., \&Popa, A.M. (2020). Nudging generation Y towards sustainable development. In Collective capacity building- Shaping Education and Communication in Knowledge Society. Brill/Sense Publishers. https://doi.org// https://doi.org//10.1163/9789004422209.

Exter, N., Grayson, D., \& Maher, R. (2013). Facilitating organizational change for embedding sustainability into academia: a case study. Journal of Management Development, 32(3), 319-332. https://doi.org//10.1108/02621711311318328.

Filho, W. L. (2011). About the Role of Universities and Their Contribution to Sustainable Development, Higher Education Policy, 24, 427 - 438. https://doi.org// 10.1057/hep.2011.16.

Fyfield, M., Henderson, M., Heinrich, E., \& Redmond, P. (2019). Videos in higher education: Making the most of a good thing. Australasian Journal of Educational Technology, 35(5), 1-7. https://doi.org//10.14742/ajet.5930.

Garrecht, C., Bruckermann, T., \& Harms, U.. (2018). Students' Decision-Making in Education for Sustainability-Related Extracurricular Activities-A Systematic Review of Empirical Studies. Sustainability, 10(11), 1-19, https://doi.org//10.3390/su10113876. 
Howarth, R., Ndlovu, T., Ndlovu, S., Molthan-Hill, P., \&Puntha, H. (2019) Integrating education for sustainable development into a higher education institution: beginning the journey. Emerald Open Research, 1-9. https://doi.org//10.12688/emeraldopenres.13011.1.

Hsiao, H.-S., Chang, C.-S., Lin, C.-Y., Chang, C.-C., \& Chen, J.-C. (2014). The influence of collaborative learning games within different devices on student's learning performance and behaviours. Australasian Journal of Educational Technology, 30(6), 652-669. https://doi.org//10.14742/ajet.347.

Kostyuchenko, N., \& Smolennikov, D. (2016). Active Teaching Methods in Education for Sustainability as Applied in Good Practices of Local Communities, Studia Periegetica 1(15), 145-158.

Kopnina, H., \&Meijers, F. (2012). Education for sustainable development (ESD) Exploring theoretical and practical challenges. International Journal of Sustainability in Higher Education, 15(2), 188-207. https://doi.org// 10.1108/IJSHE-07-2012-0059.

Laurie, R., Nonoyama-Tarumi, Y., Mckeown, R., \&Hopkinsesd, C. (2016). Contributions of Education for Sustainable Development (ESD) to Quality Education: A Synthesis of Research. Journal of Education for Sustainable Development 10(2), 226-242. https://doi.org//10.1177/0973408216661442.

Petroulis, I., Tzelepi, M., \& Papanikolaou, K. (2019). On the Design of Gamification Elements in Moodle Courses. Games and learning alliance. Springer, 428-437.

Rozman, T., \& Donath, L. (2019). The Current State of the Gamification in E-Learning. Mednarodno Inovativno Poslovanje = Journal of Innovative Business and Management, 11(3), 5-19. https://doi.org// 10.32015/jibm/2019-11-3-2.

Rozman, T., \& Rozman, M. F. (2020). Education for Sustainability: Learning Methods and the Current State in Slovenia (a Preliminary Study). International Journal of Smart Education and Urban Society (IJSEUS), 11(1), 41-63. https://doi.org//10.4018/IJSEUS.2020010104.

Slager, R., Pouryousefi, S., Moon, J., \& Schoolman, E. (2020). Sustainability Centres and Fit: How Centres Work to Integrate Sustainability Within Business Schools. Journal of Business Ethics, 161, 375-391 https://doi.org//10.1007/s10551-018-3965-4.

Smith, P.A., \& Sharicz, C. (2013). The Learning through the Lens of Complexity Theory. EDU/WKP (11), OECD. https://doi.org//10.1787/19939019.

Stoeva, Z. (2018). What Are the Benefits of E-Learning for Teachers Retrieved from: https://www.vedamo.com/knowledge/benefits-of-e-learning-for-teachers/.

Suriyankietkaew, S., \& Hallinger, P. (2018). Empirical Research on Education for Sustainable Development in Sufficiency-Based Schools. European Journal of Sustainable Development, 7(3), 205. https://doi.org//10.14207/ejsd.2018.v7n3p205.

Thaler, R., Sunstein, Cass. (2017). Nudge. Improving Decisions about Helth, Wealth and Happiness. Penguin books, 2009.

UNESCO, (2018) Guidebook on Education for Sustainable Development for Teachers. Effective teaching and learning in teacher education institutions in Africa.

Zarra, A., Simonelli, F., Lenaerts, K., Luo, M., Baiocco, S., Ben, S., Li, W., Echikson, W., \& Kilhoffer, Z. (2019). Sustainability in the Age of Platforms. Centre for European Policy Studies.

Wakunuma, K., \& Jiya, T. (2019). Stakeholder Engagement and Responsible Research \& Innovation in promoting Sustainable Development and Empowerment through ICT. European Journal of Sustainable Development, 8(3), 275. https://doi.org//10.14207/ejsd.2019.v8n3p275 